\title{
PROTEIN PATTERNS OF YEAST DURING SPORULATION
}

\author{
by
}

\author{
JENS G. LITSKE PETERSEN and MORTEN C. KIELLAND-BRANDT \\ Department of Physiology. Carlsberg Laboratory \\ Gamle Carlsberg Vej 10, DK-2500 Copenhagen Valby \\ and
}

TORSTEN NILSSON-TILLGREN

Institute of Genetics, University of Copenhagen

Oster Farimagsgade 2A, DK-1353 Copenhagen K

Keywords: Saccharomyces cerevisiae, meiosis, protein synthesis, two-dimensional gel
electrophoresis

High resolution two-dimensional gel electrophoresis was used to study protein synthesis during synchronous meiosis and ascospore formation of Saccharomyces cerevisiae. The stained protein patterns of samples harvested at any stage between meiotic prophase and the four-spore stage in two sporulating strains showed the same approximately 250 polypeptides. Of these only a few seemed to increase or decrease in concentration during sporulation. The characteristic pattern of sporulating yeast was identical to the pattern of glucose-grown stationary yeast cells adapted to respiration. The latter type of cells readily initiates meiosis when transferred to sporulation medium. This pattern differed from the protein patterns of exponentially growing cells in glucose or acetate presporulation medium. Five major proteins in stationary and sporulating yeast cells were not detected in either type of exponential culture. Two-dimensional autoradiograms of [35S]methionine-labelled yeast proteins revealed that some proteins were preferentially labelled early during sporulation. while other proteins were labelled at later stages. These patterns differed from the autoradiograms of exponentially growing yeast cells in glucose presporulation medium in a number of spots. No differences were observed when stained gels or autoradiograms of sporulating cultures and non-sporulating strains in sporulation medium were compared.

Abbreviations: $\mathrm{PMSF}=$ phenylmethylsulfonyl fluoride, $\mathrm{SDS}=$ sodium dodecyl sulfate, $\mathrm{TCA}=$ trichloroacetic acid. 


\section{INTRODUCTION}

Meiosis in the yeast Saccharomyces cerevisiae occurs during early stages of sporulation of a diploid cell and eventually results in the formation of an ascus containing four haploid ascospores. This complex unicellular differentiation process is under both genetical and physiological control. Only diploid cells heterozygous at the mating-type locus $(a / \alpha)$ are able to undergo meiosis and ascospore formation, while haploids ( $a$ or $\alpha$ ) and diploids homozygous for matingtype $(a / a$ or $\alpha / \alpha)$ are not $(11,21)$. Synchronous sporulation is initiated when cells preadapted to oxidative growth are transferred to a potassium acetate sporulation medium $(4,10,22)$.

Our understanding of the role of the protein synthesis which accompanies meiosis and ascospore formation is still limited. Sporulation is stopped at any stage by cycloheximide showing that continued protein synthesis is necessary to complete meiosis and ascospore formation. There are two periods of protein synthesis: An early phase during meiotic DNA replication and a late phase at the time of spore formation. The internal amino acid pool and protein turnover is sufficient to provide amino acids for new protein synthesis (9). The levels of several enzymes have been studied during sporulation. The specific activities of some enzymes are raised severalfold, while other enzymes are inactivated during sporulation $(2,3,14)$.

In a recent study of macromolecule synthesis and breakdown during sporulation of yeast Hopper et al. (13) found that the early rate of protein synthesis in sporulation medium is similar in sporulating $(a / \alpha)$ and in non-sporulating cells, $(a / a)$ and $(\alpha / \alpha)$. Furthermore, onedimensional gel electropherograms of labelled proteins synthesized in sporulation medium were identical for sporulating and non-sporulating strains. However, the autoradiogram patterns of vegetative, exponentially growing cells differed from those obtained from cells in sporulation medium.

In an additional effort to identify proteins specific for meiosis, we have used high resolution two-dimensional gel electrophoresis (17) to study protein synthesis during sporulation of yeast with special emphasis on induction of meiosis and the time period of meiotic development. Most experiments were done with the high cell density sporulation procedure described in a previous paper (18), since this system facilitated protein extractions and radioisotope labelling of proteins with relatively high activities.

\section{MATERIALS AND METHODS}

\subsection{Strains}

Two diploid, sporulating yeast strains of Saccharomyces cerevisiae were used in this study, strain 11D (genotype a/a ade $2 /+$ ade6 $/+$ his $8 /+$ leul $/+$ lys $7 /+)(18)$, and strain 212-1 (genotype a/ $\alpha$ cdc4 $/ c d c 4$ adel $/+$ ade2/ ade2-R8 urall+ tyrll+ his $7 /+$ lys $2 /+$ gall $/+$ let $8 /+$ canl-11l+) $(12,24)$, kindly provided by B. BYERs, Department of Genetics, University of Washington, Seattle, USA.

Two non-sporulating diploids, strains C77-11NS2 $(a / a)$ and C77-11NS3 $(\alpha / \alpha)$ were derived from 11D after UV-irradiation and selection for non-sporulators by identifying nonsporulating colonies with the ether method (7). This procedure gives strains that are essentially isogenic with strain $11 \mathrm{D}$ except for mating-type. Mating-types and diploidy of the two strains were assured by crosses with haploid and diploid tester strains, followed by sporulation and dissection.

Haploid strains used were: C77-11-05 (a ade2 leu1), C77-11-08 ( $a$ ade2), C77-11-09 ( $\alpha$ ade2 ade6 leul), and C77-11-12 ( $\alpha$ ade2 lys 7$)$. These strains were segregants of strain 11D obtained after sporulation and dissection.

\subsection{Growth and sporulation conditions}

The high cell density sporulation procedure used with strain 11D, employing a sporulation medium with yeast extract $(1 \%$ potassium acetate, $0.1 \%$ yeast extract, $0.05 \%$ glucose, pH6.5) was described in detail by PETERSEN et al. (18). The same procedure was used for the study of non-sporulating strains under sporulation conditions.

Sporulation of strain 212-1 was as described by Simchen et al. (25): Cells were grown exponentially at $20{ }^{\circ} \mathrm{C}$ (permissive temperature for the $c d c 4$ mutation) in PSP2 presporulation medium ( $1 \%$ potassium acetate, $0.67 \%$ Bacto yeast nitrogen base without amino acids, $0.1 \%$ Bacto yeast extract in $0.05 \mathrm{~m}$-potassium phtalate 
buffer, $\mathrm{pH} 5.0$ ) supplemented with adenine (22), to a cell density of $0.6-1.5 \cdot 10^{7}$ cells $\cdot \mathrm{ml}^{-1}$, and then shifted to sporulation medium $(0.3 \%$ potassium acetate, $0.02 \%$ raffinose) (19). This sporulation system yielded $65-70 \%$ asci in 30 hours.

\subsection{Protein synthesis of strain 11D}

Protein synthesis during sporulation of $11 \mathrm{D}$ was measured by the incorporation of ${ }^{14} \mathrm{C}$ protein hydrolysate into hot TCA-precipitable material during $20 \mathrm{~min}$ pulses $(16,20)$ : At various stages of meiosis duplicate $0.5 \mathrm{ml}$ samples of sporulating cultures were taken. The cells were pelleted by centrifugation at $3.000 \times$ $\mathrm{g}$ for $2 \mathrm{~min}$ and resuspended in $0.5 \mathrm{ml}$ of modified sporulation medium without yeast extract ( $1 \%$ potassium acetate, $0,05 \%$ glucose, $\mathrm{pH}$ 6.0) with $0.5 \mu \mathrm{Ci} \cdot \mathrm{ml}^{-1}$ of $\left[\mathrm{U}-{ }^{14} \mathrm{C}\right]$ protein hydrolysate (Radiochemical Centre, Amersham) and $0.5 \mathrm{mg}^{-1} \mathrm{ml}^{-1}$ of Casamino acids (Difco). After incubation for $20 \mathrm{~min}$ at $25^{\circ} \mathrm{C}$ with aeration, $0.5 \mathrm{ml}$ of $10 \%(\mathrm{w} / \mathrm{v}) \mathrm{TCA}$ including $1 \mathrm{mg} \cdot \mathrm{ml}^{-1}$ of Casamino acids was added to stop further incorporation. The samples were heated for $20 \mathrm{~min}$ at $90^{\circ} \mathrm{C}$, filtered onto glass fiber filters (Schleicher and Schuell Inc.), washed with $5 \% \mathrm{TCA}$, dried overnight at $65^{\circ} \mathrm{C}$, and counted in $5 \mathrm{ml}$ of $0.4 \%$ Omnifluor (New Enland Nuclear) in toluene using a Beckman scintillation counter.

\subsection{Labelling of proteins for autoradiography}

Presporulation and sporulation cultures were labelled at various times with [ $\left.{ }^{35} \mathrm{~S}\right]$ methionine as described above. Labelling periods from 0.5 to 5 hours were used at isotope activities ranging from 5 to $25 \mu \mathrm{Ci} \cdot \mathrm{ml}^{-1}$ (specific activities between 150 and $750 \mu \mathrm{Ci} \cdot \mathrm{mol}^{-1}$ ) of $\mathrm{L}^{-35}{ }^{35}$ ]methionine (Radiochemical Centre, Amersham). The incorporation was stopped by the addition of $1 \mathrm{ml}$ of L-methionine $\left(1 \mathrm{mg} \cdot \mathrm{ml}^{-1}\right)$ per $10 \mathrm{ml}$ of culture. After $5 \mathrm{~min}$ the cells were collected by centrifugation and washed twice in cold water. Protein extracts for two-dimensional electrophoresis were prepared as described in section 2.5. Non-sporulating control strains in sporulation medium ( $10 \mathrm{ml}$ cultures, $2.5 \cdot 10^{8}$ cells $\cdot \mathrm{ml}^{-1}, 25$ $\left.{ }^{\circ} \mathrm{C}\right)$ were labelled with $\left[{ }^{35} \mathrm{~S}\right]$ methionine $(25$ $\left.{ }_{\mu \mathrm{Ci}} \cdot \mathrm{ml}^{-1} ; 150 \mu \mathrm{Ci} \cdot \mu \mathrm{mol}^{-1}\right)$ from 3 to 5 hours after the transfer to sporulation medium.

\subsection{Two-dimensional gel electrophoresis}

The preparation of protein extracts for twodimensional electrophoresis essentially followed the method of O'FARRELL (17): A pellet of $2.5 \cdot 10^{9}$ water washed cells was washed once in $10 \mathrm{ml}$ of $5 \mathrm{~mm}-\mathrm{MgCl}_{2}, 10 \mathrm{~mm}$-Tris- $\mathrm{HCl}, \mathrm{pH} 7.8$ $\left(4^{\circ} \mathrm{C}\right)$. The cells were resuspended in $0.8 \mathrm{ml}$ of the same buffer. Then $0.025 \mathrm{ml}$ of pancreatic ribonuclease A (Sigma no. R5125, $2 \mathrm{mg} \cdot \mathrm{ml}^{-1}$ in $0.1 \mathrm{M}-$ Tris- $\mathrm{HCl}, \mathrm{pH} 6.8$ ) and $0.025 \mathrm{ml}$ of freshly prepared phenylmethylsulfonyl fluoride (PMSF) (7 $\mathrm{mg} \cdot \mathrm{ml}^{-1}$ in absolute ethanol) were added, and the cells broken with $3 \mathrm{~g}$ of $0.45 \mathrm{~mm}$ glass beads in a Braun Melsungen MSK II Homogenizer for $90 \mathrm{sec}$ at $2,000 \mathrm{rpm}$. The homogenate was incubated with $0.025 \mathrm{ml}$ of pancreatic deoxyribonuclease I (Sigma no D0876, $2 \mathrm{mg} \cdot \mathrm{ml}^{-1}$ in 5 $\mathrm{mm}-\mathrm{MgCl}_{2}, 10 \mathrm{~mm}-\mathrm{Tris}-\mathrm{HCl}, \mathrm{pH}$ 7.8) for $5 \mathrm{~min}$ on ice. Further $0.025 \mathrm{ml}$ of PMSF solution was then added, and the homogenate, free of glass beads, was stored at $-80^{\circ} \mathrm{C}$ for not more than 2 weeks. Just prior to the first dimension isoelectric focusing $0.35 \mathrm{~g}$ urea, $0.04 \mathrm{ml}$ Nonidet NP-40 (Shell), $0.032 \mathrm{ml}$ Ampholines pH 5-7. $0.008 \mathrm{ml}$ Ampholines $\mathrm{pH}$ 3.5-10 (LKB, Sweden), and $0.1 \mathrm{ml}$ of 2-mercaptoethanol were added per $0.5 \mathrm{ml}$ of homogenate. After incubation of the mixture for $30 \mathrm{~min}$ at $25^{\circ} \mathrm{C}$ the samples were centrifuged at $10,000 \times \mathrm{g}$ for 10 $\min$.

Usually a volume of $0.025 \mathrm{ml}$ of supernatant was applied to an isoelectric focusing gel. This sample corresponded to $150-230 \mu \mathrm{g}$ of protein. Protein concentrations were determined by the Biorad Protein Assay in parallel yeast homogenates (prepared omitting Ampholines and 2mercaptoethanol) using bovine serum albumin (Sigma) as standard. In [ ${ }^{35}$ S $]$ methionine-labelled extracts the total radioactivity was determined by counting $1 \mu \mathrm{l}$ supernatant in $10 \mathrm{ml}$ of Dimilume (New England Nuclear).

Two-dimensional gel electrophoresis was performed as described by O'FaRRELI. (17) with the modifications of AmEs and NiKaIDO (1). The first dimension isoelectric focusing employed $1.6 \%$ Ampholines $\mathrm{pH} 5-7$ and $0.4 \%$ Ampholines $\mathrm{pH}$ 
3.5-10. Separation in the second dimension was in $10 \%$ polyacrylamide gels with SDS (15).

The gels were fixed for 2 hours in a solution of $50 \%$ methanol and $7 \%$ acetic acid, stained for 3 hours with $0.025 \%$ Coomassie Brilliant Blue G-250 (Sigma) in fixing solution, and destained for 5 hours in 7\% acetic acid. Autoradiograms were prepared from stained and dried gels by exposing Ilford 100 FW Rapid R film for 14 to 120 days.

\section{RESULTS}

\subsection{Protein synthesis during sporulation of strain $11 \mathrm{D}$}

Strain 11D can be induced to undergo synchronous meiosis and sporulation (18). In this sporulation procedure the cells gain the ability to sporulate at high cell densities $\left(2.5 \cdot 10^{8}\right.$ cells $\cdot \mathrm{ml}^{-1}$ ) by growth to stationary phase in a presporulation medium rich in glucose. During exponential growth and early stationary phase the cells are actively fermenting glucose, and they sporulate poorly when transferred to sporulation medium (section 2.2). After 10-14 hours in the stationary phase the cells become adapted to respiration, and are thereafter able to carry out a synchronous sporulation. After approx. 8 hours in sporulation medium the majority of cells (65-70\%) have reached meiotic prophase or metaphase $I(18,26)$. Sporulation is completed after 20-24 hours resulting in the formation of 60-65\% four-spored asci. Meiotic DNA synthesis takes place between 0 and 8 hours, which is also the period of active RNA synthesis.

In the present study protein synthesis accompanying sporulation of $11 \mathrm{D}$ was measured by the incorporation of ${ }^{14} \mathrm{C}$-protein hydrolysate into protein during $20 \mathrm{~min}$ labelling periods at various stages of sporulation. The result is shown in Figure 1. Three periods of especially active incorporation were observed; at time 0 hours, at 1.5 hours, and from 3-3.5 hours after transfer to sporulation medium. Only minor incorporation of isotope was observed after 7-8 hours. Similar curves were obtained with $\left[{ }^{3} \mathrm{H}\right.$ ]leucine using 5 and $30 \mathrm{~min}$ incorporation periods. These data suggest that protein synthesis is predominantly an early event during sporulation of strain $1 / \mathrm{D}$.

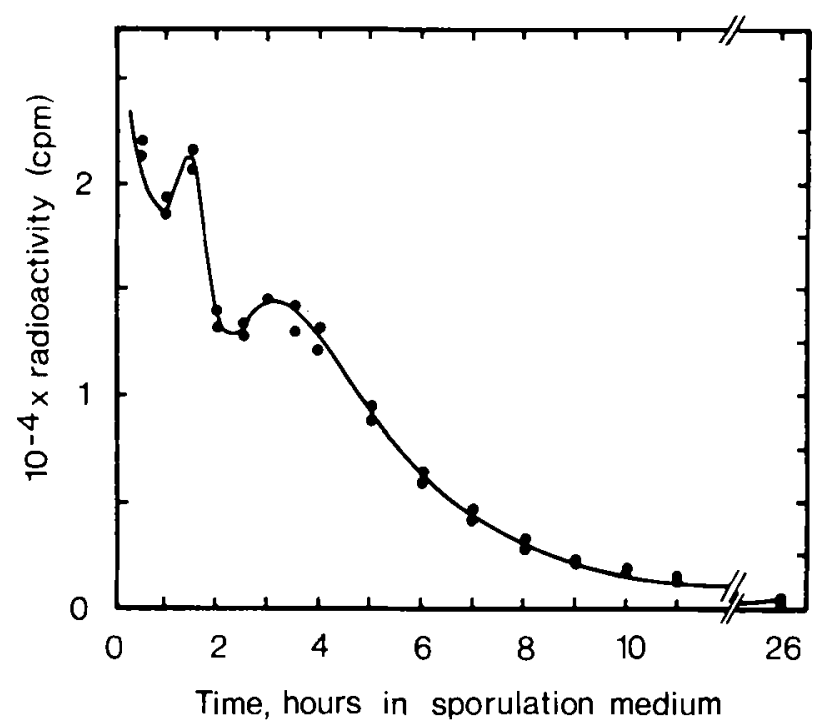

Figure 1. Protein synthesis during sporulation of yeast strain 11D. A culture of strain 11D was grown to stationary phase in glucose presporulation medium and shifted to sporulation medium at a density of $2.5 \cdot 10^{8}$ cells $\cdot \mathrm{ml}^{-1}\left(25^{\circ} \mathrm{C}\right)$. Protein synthesis was measured by the incorporation of ${ }^{14} \mathrm{C}$-protein hydrolysate in hot TCAprecipitable material during 20 min labelling periods in $0.5 \mathrm{ml}$ cultures taken at various times as described in section 2.3 . 
J. G. L. Petersen et al.: Sporulation of yeast
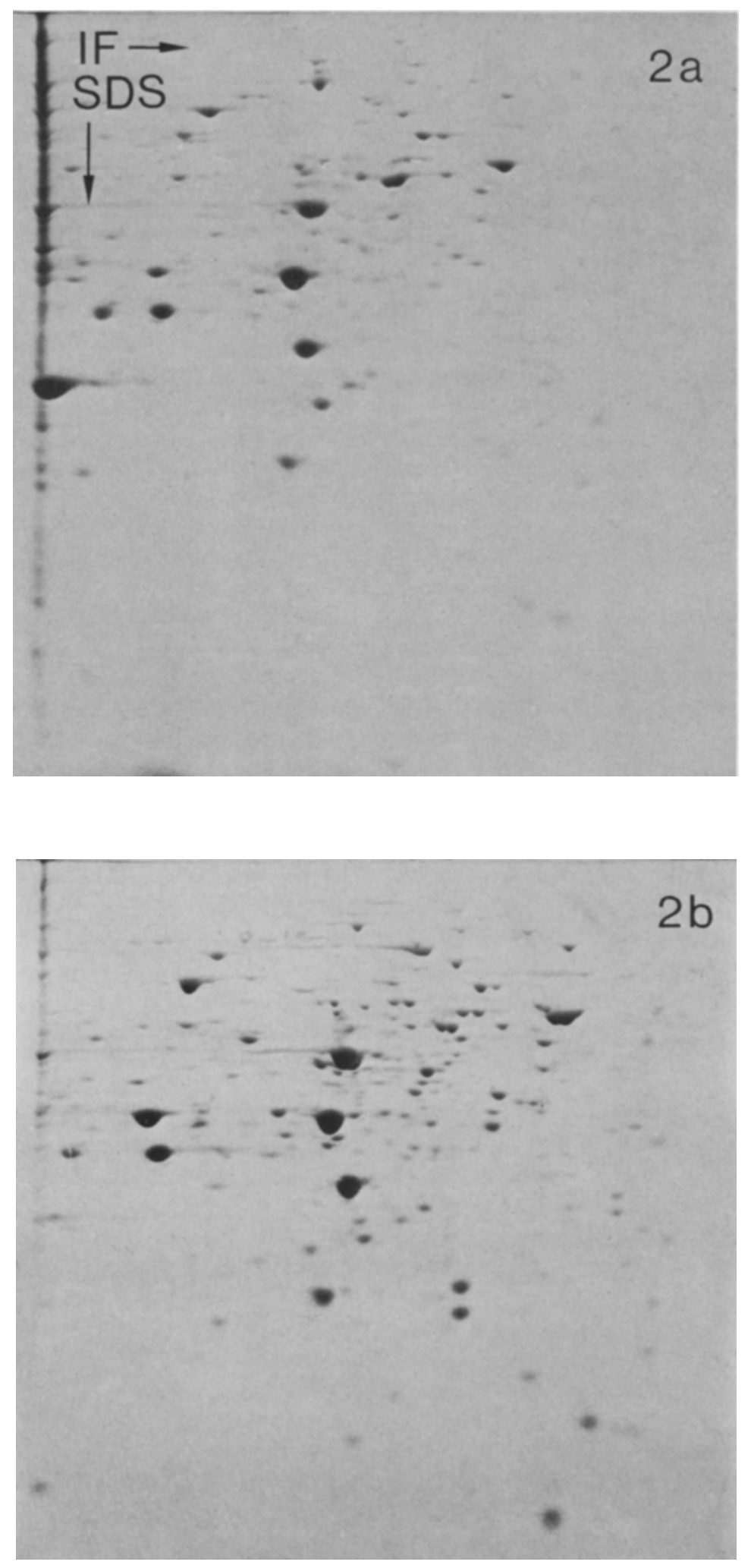


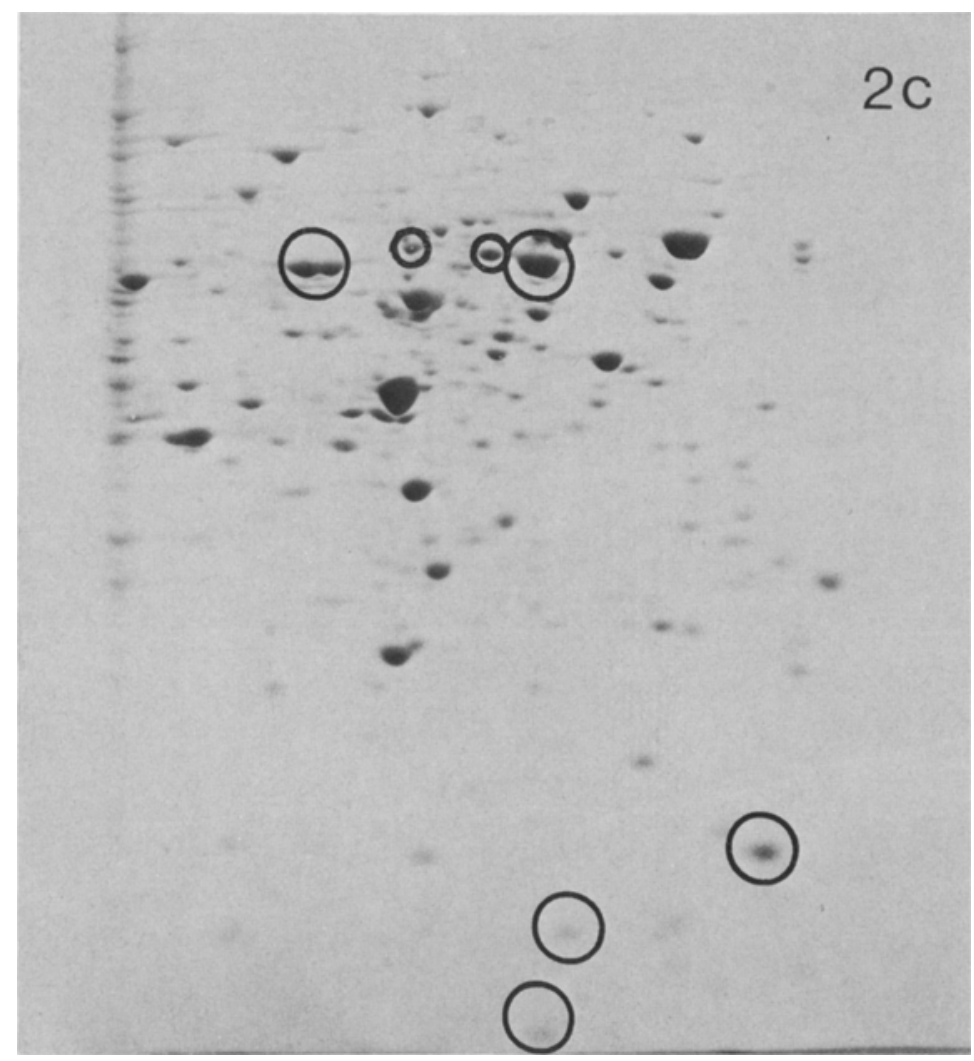

Figure 2. Two-dimensional, stained protein patterns of yeasts in presporulation media.

(a) Strain IID harvested in exponential phase (density $1.0 \cdot 10^{8}$ cells $\cdot \mathrm{ml}^{-1}$ ) in glucose presporulation medium. The cells at this stage grow by fermentation of glucose, and sporulate poorly when transferred to sporulation medium $(200 \mu \mathrm{g}$ protein applied to the gel).

(b) Strain $11 \mathrm{D}$ in stationary phase $\left(2.8 \cdot 10^{8}\right.$ cells $\left.\cdot \mathrm{ml}^{-1}\right)$ in glucose medium. The cells are in a respiratory state, and sporulate efficiently when transferred to sporulated medium $(220 \mu \mathrm{g}$ protein).

(c) Strain $212-1$ in exponential phase $\left(6.0 \cdot 10^{6}\right.$ cells $\left.\cdot \mathrm{ml}^{-1}\right)$ in PSP2 acetate presporulation medium. The cells grow by respiration, and sporulate efficiently when transferred to sporulation medium ( $248 \mu \mathrm{g}$ protein). The 7 encircled polypeptides were absent, or found in low concentration, during sporulation of 212-1 and 11D.

\subsection{Stained two-dimensional gels}

Synthesis of individual yeast proteins was studied by two-dimensional gel electrophoresis (17) using staining to detect the polypeptides. This technique allows detection of gross concentration changes in the large number of major yeast proteins which are separated in the gels. Some proteins may not be detected because of poor solubility, extreme isoelectric points or low molecular weights.

At various stages during vegetative growth in glucose presporulation medium or during syn- chronous sporulation, protein extracts were prepared from strain $11 \mathrm{D}$, and the yeast polypeptides separated by two-dimensional electrophoresis.

Figure 2(a) shows a typical gel of glucosegrown cells in late exponential growth (harvested at a cell density of $1.0 \cdot 10^{8}$ cells $\cdot \mathrm{ml}^{-1}$ ) and Figure 2(b) the protein pattern of cells in the respiration adapted, stationary stage (cell density $2.8 \cdot 10^{8}$ cells $\cdot \mathrm{ml}^{-1}$ ). In Figure 3 is shown a gel of sporulating cells at 8 hours.

The patterns of exponentially growing cells 


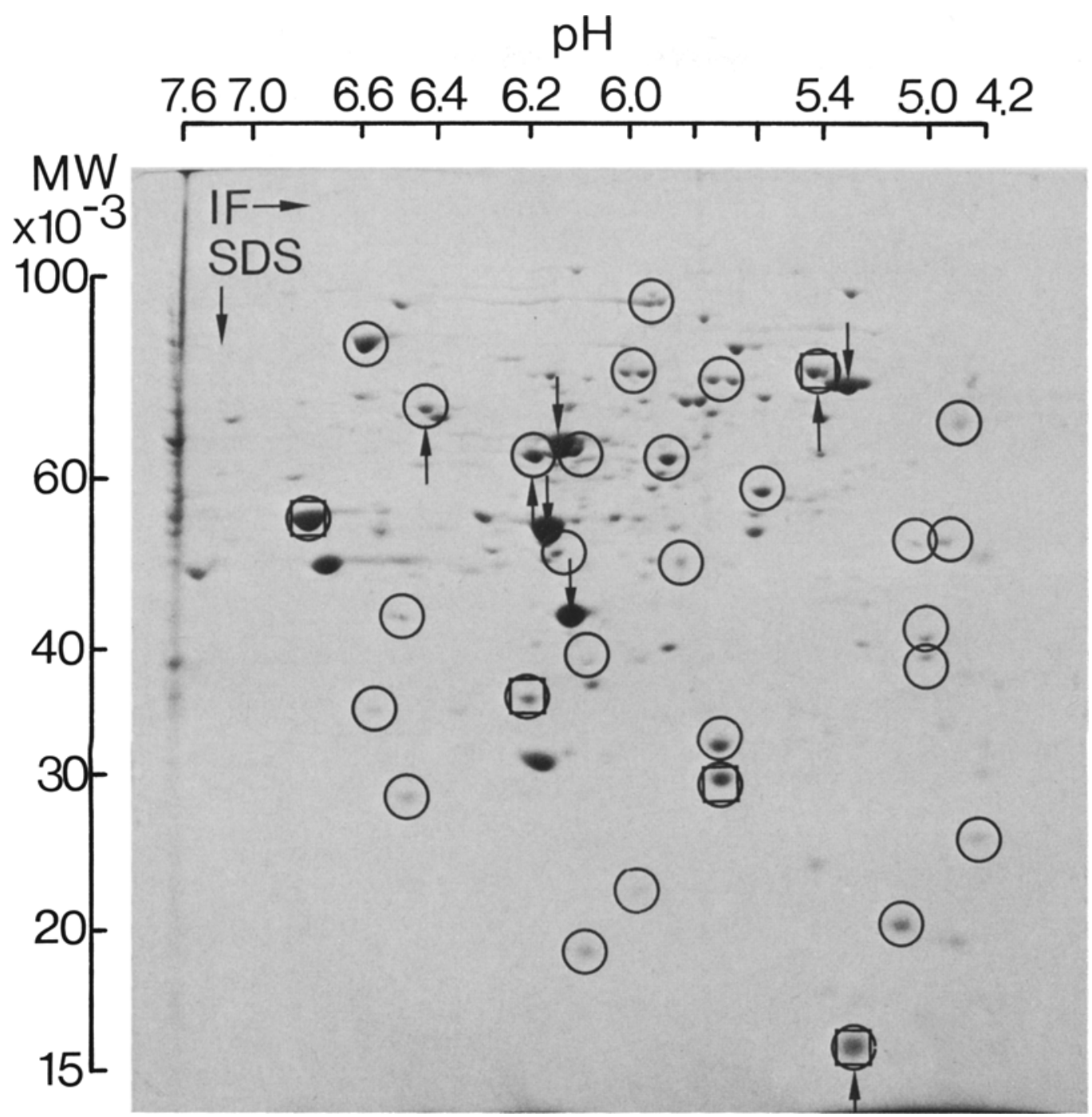

Figure 3. Two-dimensional, stained protein patterns of strain 11D during synchronous sporulation at 8 hours after transfer to sporulation medium.

At this time approximately $70 \%$ of the cells were in meiotic prophase or metaphase I, and the major parts of meiotic DNA, RNA and protein synthesis appeared to be completed. The symbols used are: $O$ for polypeptides which were absent, or found in low cencentration, during exponential growth in glucose medium; $\square$ for polypeptides which were absent, or found in low concentration, during exponential growth in PSP2 presporulation acetate medium; $\uparrow$ for polypeptides which increased and $\downarrow$ for those which decreased from 0 to 24 hours during sporulation of $11 \mathrm{D}$. Tentative scales for isoelectric points and molecular weights are included.

(sporulation incompetent) were consistently found to be less complex than the ones of respiration adapted stationary cells (sporulation competent) and sporulating cells. All polypeptides which were present in exponentially growing cells were also found in stationary and sporulating cells. Typically, 150-180 proteins were identified in a single gel of exponentially growing cells, while $210-250$ proteins were observed in gels of stationary and sporulating cultures. 
Therefore, in the order of $60-80$ additional proteins appeared when cells went from fermentative growth into the oxidative stationary state ( 30 of the new or increased proteins are encircled in Figure 3). No new proteins appeared and none disappeared when stationary yeast cells were transferred to sporulation medium (compare Figures 2(b) and 3). Furthermore, between time 0 and 24 hours (with sampling times at $0.25,1$, $3,4,5,7,8,12,15$ and 24 hours) there seemed to be no qualitative changes in the patterns. As an example the 8 hour gel is shown. We observed intensity changes in 8 major yeast proteins between 0 and 24 hours; 4 proteins seemed to increase in concentration during sporulation, and 4 proteins seemed to decrease. These proteins are marked with upward and downward arrows, respectively, in Figure 3. No proteins were observed to increase or decrease in concentration during a limited interval of sporulation.

Another sporulation system was analysed in a similar manner in order to see if the protein patterns could be altered by using another strain or other physiological conditions. The sporulation of strain 212-1 is conditioned by growth in a presporulation medium (PSP2) with acetate as the carbon source. Sporulation is induced when exponentially growing cells are transferred to potassium acetate-raffinose sporulation medium (section 2.2). The stained gels from cells at various stages of meiosis and ascospore formation (at 8,16 and 28 hours after transfer to sporulation medium) were indistinguishable from corresponding gels from strain 11D. The 4 proteins which were found to decrease in concentration during sporulation of $11 \mathrm{D}$, likewise decreased during sporulation of $212-1$, and 1 protein with an apparent isoelectric point of 5.4 and a molecular weight of 80,000 increased in concentration. The latter protein corresponds to one of the four proteins increasing in concentration in $11 \mathrm{D}$.

The pattern of strain 212-1 in exponential phase on PSP2 presporulation medium is shown in Figure 2(c). The pattern is very similar, but not identical, to the patterns of sporulating cells. We have encircled 7 proteins in Figure 2(c) which decreased considerably in concentration during the 8 hours after transfer of the exponentially growing cells to sporulation me- dium, and marked 5 proteins with boxes in Figure 3 which turned up during sporulation of 212-1 after transfer from the presporulation medium. Four of the 5 proteins were not observed when 212-1 was grown to stationary phase in acetate medium. The 5 proteins belonged to the 30 major proteins found prominently or exclusively in stationary and sporulating cells of strain 11D. It is concluded that significant strain specificities were not encountered but that the physiological condition - as exemplified by the acetate presporulation medium - can have a considerable effect on the protein composition.

\subsection{Autoradiogram patterns during exponential growth and sporulation of strain 11D}

In order to study whether specific proteins are synthesized at different stages of sporulation and whether these differ from the proteins synthesized during vegetative growth, cultures of strain $11 \mathrm{D}$ were labelled with [ $\left.{ }^{35} \mathrm{~S}\right]$ methionine and the two-dimensional autoradiogram patterns compared.

An autoradiogram of exponentially growing cells in glucose presporulation medium labelled for 1 hour with $\left.{ }^{35} \mathrm{~S}\right]$ methionine is shown in Figure 4(a). The pattern is more complex than the comparable Coomassie Blue stained pattern in Figure 2(a), but, with very few exceptions, the protein spots identifiable by staining were labelled with $\left.{ }^{[35} \mathrm{S}\right]$ methionine, and many heavily stained proteins were also found intensely labelled in the autoradiograms.

A protein synthesis pattern of strain 11D labelled early during sporulation (from 0.25 to 1.25 hours after transfer into sporulation medium) is shown in Figure 4(b). Also this pattern is similar to, but more complex than the one obtained by staining. At least 20 proteins marked in Figure 4(b) were found to be synthesized at this stage, but not in exponentially growing cells, while at least 22 proteins encircled in Figure 4(a) were predominantly labelled in exponential cells, but not in sporulating cells. Minor changes in the protein synthesis patterns were observed from early to later labelling periods during sporulation. Nine proteins which were preferentially labelled at early times are indicated in Figure 4(b) with triangles, while 
J. G. L. Petersen et al.: Sporulation of yeast
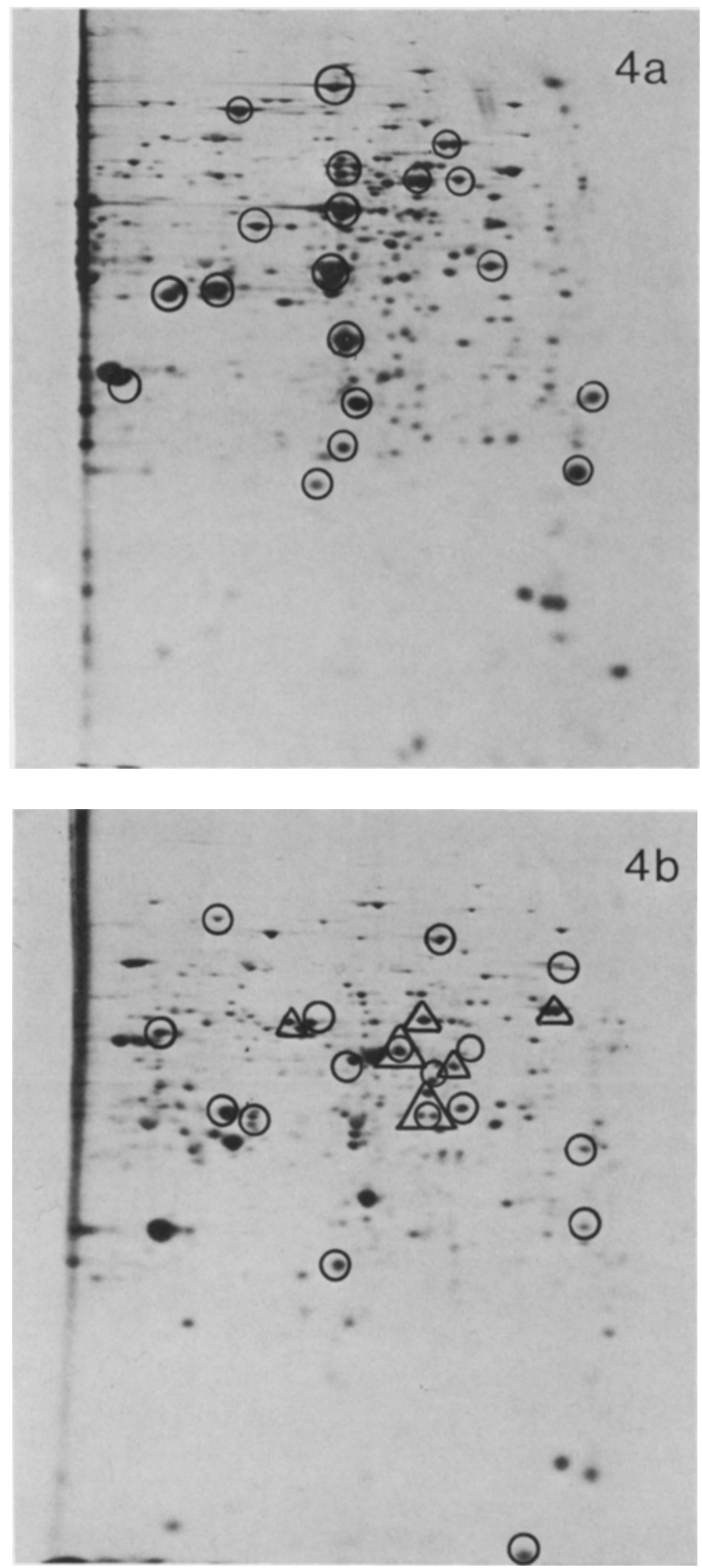

Carlsberg Res. Commun. Vol. 44, p. 149-162, 1979 


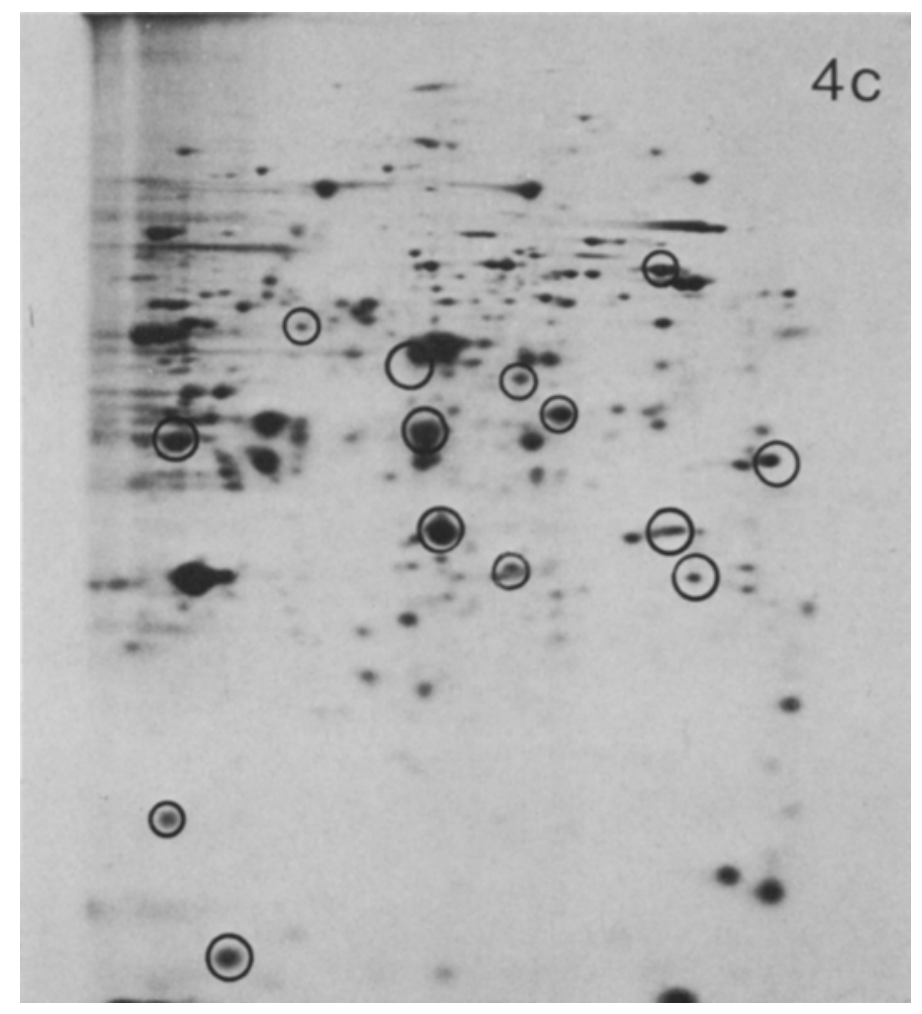

Figure 4. Autoradiograms of labelled proteins of strain 11D.

(a) Exponentially growing cells (density $\left.5.0 \cdot 10^{7} \mathrm{cells} \cdot \mathrm{ml}^{-1}\right)$ in glucose medium $(20 \mathrm{ml}$ culture) were labelled with [ ${ }^{35} \mathrm{~S}$ ] methionine $\left(25 \mu \mathrm{Ci} \cdot \mathrm{ml}^{-1} ; 750 \mu \mathrm{Ci} \cdot \mu \mathrm{mol}^{-1}\right)$ for 1 hour. A sample of $2.7 \cdot 10^{6} \mathrm{cpm}$ was separated by twodimensional gel electrophoresis. Exposure time 40 days. Polypeptides which were predominantly or exclusively labelled in exponentially growing cells are encircled.

(b) Sporulating culture labelled early for a 1 hour period (time $0.25-1.25$ hours after transfer into sporulation medium) with [ ${ }^{35}$ S]methionine $\left(10 \mu \mathrm{Ci} \cdot \mathrm{ml}^{-1} ; 150 \mu \mathrm{Ci}^{-1} \mu \mathrm{mol}^{-1}\right)$. A sample of $0.8 \cdot 10^{6} \mathrm{cpm}$ was electrophoresed. Exposure time 20 days. Symbols used are: $O$ for new or increased spots in comparison with cells growing exponentially; $\triangle$ for polypeptides which were predominantly synthesized early during sporulation.

(c) Sporulation culture labelled at a later stage for a 4 hour period (time 8-12 hours after transfer into sporulation medium) with [ $\left.{ }^{35} \mathrm{~S}\right]$ methionine $\left(30 \mu \mathrm{Ci} \cdot \mathrm{ml}^{-1} ; 450 \mu \mathrm{Ci} \cdot \mu \mathrm{mol}^{-1}\right)$. A sample of $1.3 \cdot 10^{6} \mathrm{cpm}$ was used. Exposure time 20 days. Encircled protein spots were intenser than at earlier stages of sporulation (labelling periods between 0 and 2 hours).

proteins labelled intensely at later stages of sporulation are encircled in Figure 4(c). The latter shows an autoradiogram of proteins from cells labelled from $8-12$ hours after transfer into sporulation medium. We have not been able to identify proteins which are only synthesized during a specific sporulation stage.

\subsection{Autoradiogram patterns of sporulating and non-sporulating strains}

The protein patterns of strain 11D and nonsporulating derivatives of this strain were studied in order to make comparisons which were less dependent on the physiological conditions of growth. Two diploids homozygous for mating-type, C77-11NS2 $(a / a)$ and C77-11NS3 $(\alpha / \alpha)$, and 4 haploids consisting of tow $a$ strains 
J. G. L. Petersen et al.: Sporulation of yeast
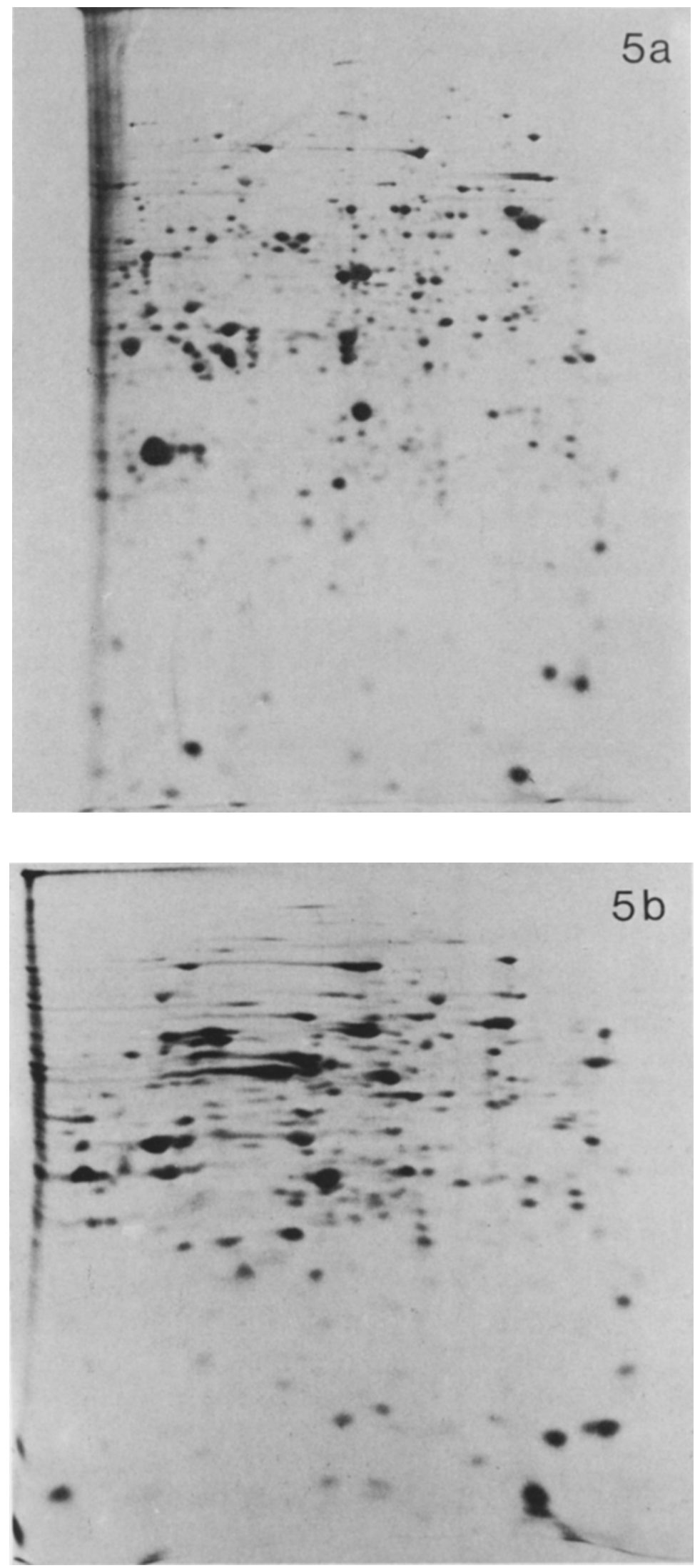


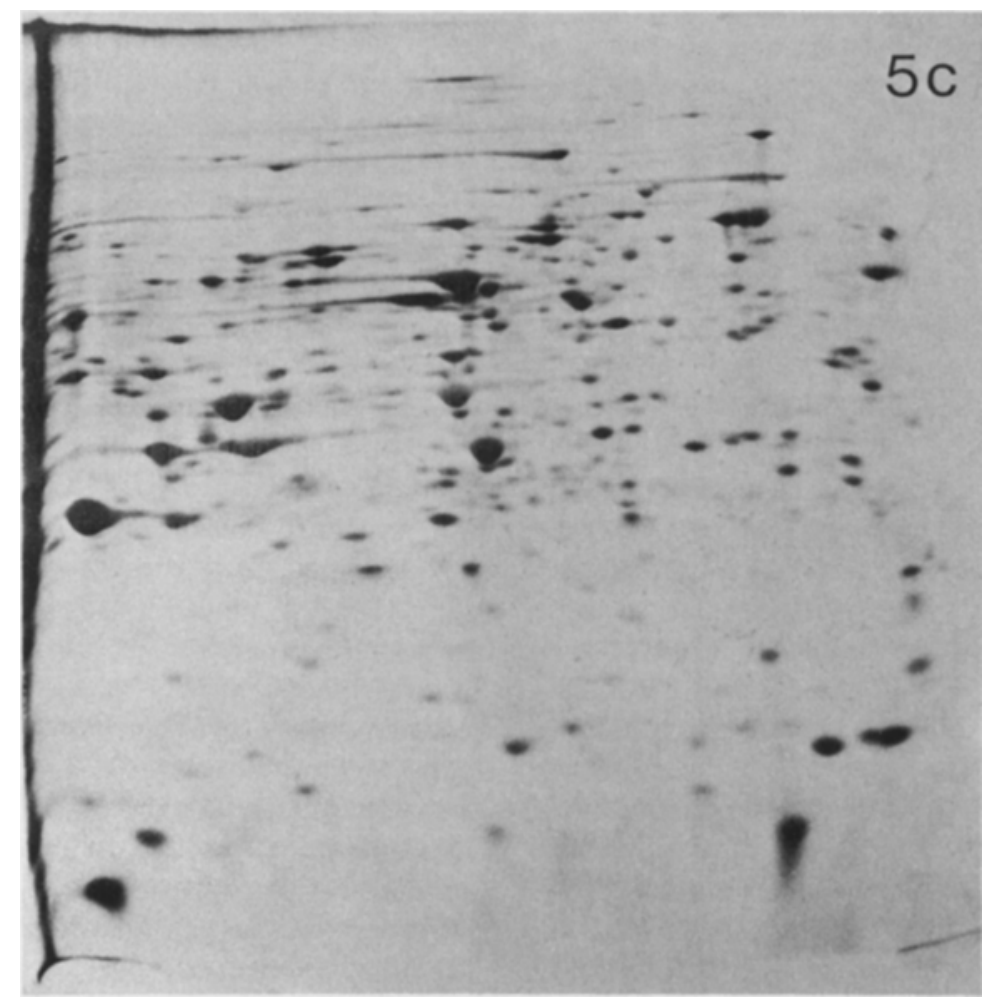

Figure 5. Autoradiograms of [ $\left.{ }^{35} \mathrm{~S}\right]$ methionine-labelled sporulating and non-sporulating diploids.

The strains were grown to stationary phase in glucose presporulation medium, and shifted to sporulation medium at a cell density of $2.5 \cdot 10^{8} \mathrm{cells} \cdot \mathrm{ml}^{-1}\left(25^{\circ} \mathrm{C}\right)$. The cultures were labelled with $\left[{ }^{35} \mathrm{~S}\right]$ methionine from 3 to 5 hours after the transfer into sporulation medium as described in section 2.4.

(a) Autoradiogram of sporulating strain $11 \mathrm{D}(a / \alpha)$; sample $0.8 \cdot 10^{6} \mathrm{cpm}$, exposure time 120 days. (b) Nonsporulating strain C77-11 NS2 (a/a), sample $2.9 \cdot 10^{6} \mathrm{cpm}$, exposure time 38 days. (c) Non-sporulating strain C77-1 $1 \mathrm{NS} 3(\alpha / \alpha)$; sample $2.5 \cdot 10^{6} \mathrm{cpm}$, exposure time 35 days.

and two $\alpha$ strains were grown in glucose presporulation medium to stationary phase and shifted to sporulation medium. After 3 hours in sporulation medium the cells were labelled for 2 hours with [ $\left.{ }^{35} \mathrm{~S}\right] \mathrm{methionine}$. At 5 hours protein extracts were prepared and separated by twodimensional electrophoresis. The stained patterns and autoradiograms were compared to those of strain 11D prepared from cells shifted in the same way to sporulation medium but known to undergo meiosis. The autoradiograms of strain 11D and the non-sporulating diploids, C77-11NS2 and C77-11NS3, are shown in Figures 5(a), (b) and (c), respectively. The autoradiograms are very similar and no reproducible differences could be detected. Thus the same identifiable proteins were labelled during early stages after transfer into sporulation medium in both sporulating and non-sporulating diploids. The haploid strains gave also very similar labelling patterns upon shift into sporulation medium.

\section{DISCUSSION}

Protein synthesis during sporulation of strain I1D was found to take place between 0 and 8 hours. Similar results have been obtained with other sporulation systems $(6,9,13,16)$. Changes of cell membrane permeability for amino acids during sporulation could occur and the incorporation curve need therefore not reflect 
in detail the true kinetics of protein synthesis (6, 16).

Changes in concentration and synthesis of individual polypeptides as detected by staining and radiography, respectively, was based on a visual comparison of size and intensity of particular spots from one gel to another. Though the reproducibility of a two-dimensional gel is good, we found it necessary to repeat the experiments several times in order to ensure that observed differences were not artifacts. The individual experiments were done at least 4 times and autoradiograms exposed for varying lengths of time. Only differences which were consistently observed in all experiments were registered. The method allows only observation of rather large changes in the staining intensity of radioactivity of major protein spots. Changes in minor components are not traceable in the complex gels.

As cells went from exponential growth in glucose medium into the stationary phase, which makes them competerit for sporulation, many new proteins were detected. In contrast, no qualitative differences were observed between stationary phase cells and cells in sporulation medium. Exponential growth in glucose is mainly by fermentation, while the stationary and sporulating cells are in a respiratory state with extensive RNA and protein turnover (5). We therefore suggest that most of the differences observed concern enzymes required for respiratory metabolism as well as ribonucleases and proteases. Since only a few quantitative changes in the stained patterns of 11D cells were observed between stationary phase and sporulation, it seems that most major proteins necessary for meiosis are already present in the stationary phase.

Yeast cells derepressed for respiration can be obtained by exponential growth in an acetate presporulation medium (22), as is used here for the sporulation of strain 212-1. Rather similar, but not identical patterns, were obtained from these exponentially growing cells of 212-1 and from cells in sporulation medium. Five new proteins appeared in the cells upon transfer into sporulation medium, four of which were also absent when 212-1 was grown to stationary phase in acetate medium. The data for the two strains show that stationary cells in glucose medium are more closely related to the sporulative state than are acetate grown cells. The five proteins may have a role in meiosis and spore formation.

Both the stained gel patterns and autoradiograms of pulse-labelled proteins of strain 11D were unable to reveal the appearance of new proteins during sporulation, indicating that the major part of the protein synthesis observed early in sporulation is a turnover synthesis. The changes of quantitative nature which were observed during sporulation of strain 11D might reflect the activation and inactivation known to occur for various enzymes during sporulation (2, $3,14)$. Our observation that the autoradiogram patterns only differed quantitatively in the course of meiosis is in contrast to the finding of Schultz and Wasserman (23) that new proteins appeared as meiosis proceeded from diplotene to metaphase II in mammalian oocytes.

It is to be expected that meiosis specific proteins are synthesized by cells transferred into sporulation medium. Such proteins may be affected in conditional mutants which are heat sensitive for sporulation, but not for vegetative growth (8). In addition to the experiments with the strains $11 \mathrm{D}$ and 212-1 described above, the identification of meiosis specific proteins was also sought by comparing strain 11D and nonsporulating diploid and haploid derivatives from it. Positively identified differences were not obtained in stained gels or autoradiograms between the sporulating and the non-sporulating strains after transfer to sporulation medium. Apparently the amount of meiosis specific proteins in yeast cells relative to other proteins is small and improved techniques will have to be employed for their identification.

\section{ACKNOWLEDGEMENTS}

The authors wish to thank B. E. CHRISTENSEN and S. Holmberg for advice and fruitful discussions, and B. WILKEN for excellent tochnical assistance. The support and encouragement and the critical reading of this manuscript by Professor D. voN WETtSTEIN is gratefully acknowledged. 


\section{REFERENCES}

1. Ames, G. F. \& K. NiKaido: Two-dimensional gel electrophoresis of membrane proteins. Biochemistry 15, 616-623 (1976).

2. Betz, H. \& U. Weiser: Protein degradation during yeast sporulation. Enzyme and cytochrome patterns. Eur. J. Biochem. 70, 385-395 (1976)

3. Chen,A. W. \& J. J. Miller: Proteolytic activity of intact yeast cells during sporulation. Can. J. Microbiol. 14, 957-964 (1968)

4. CROES, A. F.: Induction of meiosis in yeast. I. Timing of cytological and biochemical events. Planta (Berl.) 76, 209-226 (1967)

5. Croes, A. F.: Induction of meiosis in yeast: II. Metabolic factors leading to meiosis. Planta (Berl.) 76. 227-237 (1967)

6. Croes, A. F., G. J. L. M. De Vries Geertrui \& J. M. J. M. Steisns: Amino acid uptake and protein synthesis during early meiosis in Saccharomyces cerevisiae. Planta (Berl.) 139, 93-96 (1978)

7. DAWES. I. W. \& I. D. HARDIE: Selective killing of vegetative cells in sporulated yeast cultures by exposure to diethyl ether. Molec. gen. Genet. 131, 281-289 (1974)

8. Esposito, M. S. \& R. E. Esposito: The genetic control of sporulation in Saccharamyces. I. The isolation of temperaturesensitive sporulationdeficient mutants. Genetics 61, 79-89 (1969)

9. Esposito, M. S., R. E. Esposito, M. Arnaud \& H. O. Halvorson: Acetate utilization and macromolecular synthesis during sporulation of yeast. J. Bact. 100, 180-186 (1969)

10. FOWELL, R. R.: Sporulation and hybridization of yeasts. In: The Yeasts. A. H. Rose and J. S. Harrison eds., Academic Press, London and New York. Vol I, 303-383 (1969)

11. Friss, J. \& H. Roman: The effect of mating-type alleles on intragenic recombination in yeast. Genetics 59, 33-36 (1968)

12. Hartwell, L. H., R. K. Mortimer, J. Culotti \& M. CuLotrI: Genetic control of the cell division cycle in yeast. V. Genetic analysis of $c d c$ mutants. Genetics 74, 267-286 (1973)

13. Hopper, A. K., P. T. Magee, S. K. Welch, M. Friedman \& B. D. HaLl: Macromolecule synthesis and breakdown in relation to sporulation and meiosis in yeast. J. Bact. 119, 619-628 (1974)
14. Klar, A. J. S., A. Cohen \& H. O. Halvorson: Control of enzyme synthesis and stability during sporulation in Saccharomyces cerevisiae. Biochimie 58, 219-224 (1976)

15. Laemmu, U. K.: Cleavage of structural proteins during the assembly of the head of bacteriophage T4. Nature 227, 680-685 (1970)

16. Mills, D.: Effect of $\mathrm{pH}$ on adenine and amino acid uptake during sporulation in Saccharomyces cerevisiae. J. Bact. 112, 519-526 (1972)

17. O'Farrell, P. H.: High resolution two-dimensional electrophoresis of proteins. J. Biol. Chem. 250, 4007-4021 (1975)

18. Petersen, J. G. L., L. W. Oison \& D. Zickler: Sporulation of yeast at high cell concentrations. Carlsberg Res. Commun. 43, 241-253 (1978)

19. Pomper, S., K. M. Daniels \& D. W. McKee: Genetic analysis of polyploid yeast. Genetics 39 343-355 (1954)

20. Rodenberg, S., W. Steinderg, J. Piper, K. Nickerson, J. Vary, R. Epstein \& H. O. HALVORSON: Relationship between protein and ribonucleic acid synthesis during outgrowth of spores of Bacillus cereus. J. Bact. 96, 492-500 (1968)

21. RomaN, H. \& S. M. SANDS: Heterogeneity of clones of Saccharomyces derived from haploid ascospores. Proc. Nat. Acad. Sci. USA 39, 171179 (1953)

22. Roth, R. \& H. O. Halvorson: Sporulation of yeast harvested during logarithmic growth. J. Bact. 98, 831-832 (1969)

23. Schultz, R. M. \& P. M. Wasserman: Specific changes in the pattern of protein synthesis during meiotic maturation of mammalian oocytes in vitro. Proc. Nat. Acad. Sci. USA 74, 538-541 (1977)

24. Simchen, G.: Are mitotic functions required in meiosis? Genetics 76, 745-753 (1974)

25. Simchen, G., R. Piñon \& Y. Salts: Sporulation in Saccharomyces cerevisiar: Premeiotic DNA synthesis, readiness and commitment. Exptl. Cell Res. 75, 207-218 (1972)

26. ZiCkLER, D. \& L. W. Osson: The synaptonemal complex and the spindle plaque during meiosis in yeast. Chromosoma (Berl.) 50, 1-23 (1975) 